\title{
Charity cools on stem cells after boycott by Catholics
}

[WASHINGTON] There was a new twist last week to the debate over whether the US government should support research that uses human embryonic stem cells. It became known that the American Cancer Society (ACS) has withdrawn from a coalition that is lobbying Congress to support such research.

The society, which raises $\$ 500$ million a year, earlier this month asked the Patients' Coalition for Urgent Research - known as 'Patients' CURe' - to remove its name from the list of 31 research- and patient-advocacy groups that make up the coalition.

The ACS had come under pressure from officials of the Catholic church not to participate, while some 100 lay Catholics had withdrawn from a breast-cancer fund-raising event in the suburbs of Washington and revoked promised contributions.

The current controversy was triggered by the first report last November that human embryonic stem cells had been isolated (see Nature 396, 104; 1998). Although there is a congressional ban on federal funding for research in which human embryos are destroyed or discarded, the Department of Health and Human Services ruled that federal funding of research on stem cells is permissible provided their derivation is privately financed and is limited to the use of spare embryos from fertility clinics (see Nature 397, 185-186; 1999).

This ruling has drawn protests from antiabortionists on the grounds that it is a violation of the congressional ban to allow the government to fund research with cells that depend for their production on the destruction of embryos. Patient-advocacy groups, in contrast, support the research, which could lead to cell and tissue therapies for a range of diseases, including juvenile diabetes and Parkinson's disease.

The Patients' CURe coalition was launched in May to lobby Congress to back government funding of embryonic stem-cell research through the National Institutes of Health (NIH). The ACS's withdrawal — first reported in The New York Times - suggests that emotions are running so high that even solid research-backing organizations are feeling the heat from constituents who oppose abortion. But Greg Donaldson, a spokesman for ACS, denies that the society has reversed its position.

Donaldson says that ACS is only now formulating a position on stem-cell research, and that therefore "it is impossible for us to have reversed our position". He says that, although press material passed out at the coalition's launch included ACS among its members, the society never formally joined Patients' CURe, but simply "stood up with" it at its launch when Congress seemed about to prohibit the federal funding of stem-cell research.

The withdrawal from the coalition followed a letter on 18 May from William Cardinal Keeler of Baltimore, who heads the Secretariat for Pro-Life Activities at the National Conference of Catholic Bishops. The letter urged the ACS not to participate in the group.

Also in May, around 100 people in the Maryland suburbs of Washington withdrew from ACS's breast-cancer fund-raising event Relay for Life shortly before its launch. The group, most of them Catholic, had learned of ACS's membership of Patients' CURe, and said they could not support the society as long as it backed stem-cell research. Pledges worth several thousands of dollars were returned.

One member of the group, Tim Flynn, a private investment manager in Silver Spring, Maryland, whose wife lost her mother and 39-year-old sister to breast cancer, says that "my family and my wife's family and a large group of friends very desperately want to see progress made in cancer research and cures for a number of illnesses. [But it is] inconsistent that you would destroy life for any purpose, certainly scientific experimentation. You can't use the 'ends justify the means' rationale."

Daniel Perry, a spokesman for Patients' CURe, says that other members of the coalition have been under pressure to withdraw but have resisted. "Some groups apparently can tolerate the heat a little better than others," he says. "We're all getting hate mail."

He says that the fact that two groups have recently joined the coalition is evidence that its opponents' strategy is failing. The new groups are Hadassah, the Jewish women's group, and Prevent Blindness America.

Also last week, a senior Republican senator and a Catholic Republican congressman held a press conference with Patients' CURe to endorse federal funding of stem-cell research. Senator Strom Thurmond (Republican, South Carolina), whose daughter has juvenile diabetes, urged Congress to allow federal funding of the research. The NIH "must be actively involved in stem-cell research", he said.

And Brian Bilbray (Republican, California), who describes himself as pro-choice, declared that it was "outrageous" for Congress to tell the parents of spare embryos stored at infertility clinics that they could not "save a life with an embryo that's not going to be born".

Meredith Wadman

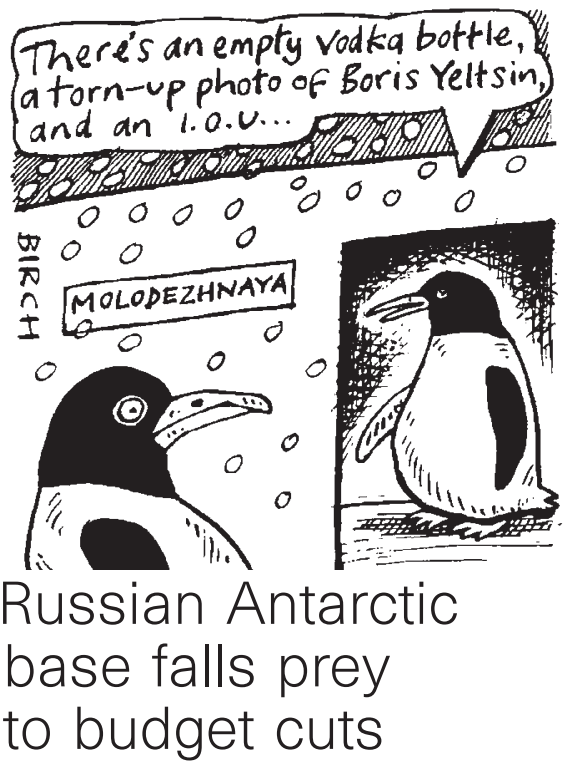

[MOscow] Russia's main Antarctic scientific base, Molodezhnaya, has been closed owing to lack of funds. The fate of the base, which has been shut "until better days", was sealed two years ago, when the Russian cabinet adopted a strategy of adapting Antarctic research to meet budgetary pressures.

Molodezhnaya, founded in 1963, was a heavy burden on the limited budget, as it has the best-developed infrastructure of Russia's Antarctic bases, including permanent living quarters for scientists, whose upkeep required large amounts of money.

Furthermore, as Valery Martyshenko, head of the the Russian Hydro-meteorological Service (RHMS), points out, the finance minister has delivered only one third of the 72.5 million rubles promised for the station.

The closure of the base means that only four of the Soviet Union's original eight stations in Antarctica are left: Mirny, Progress (which now becomes Russia's main research centre), Vostok and Novolazarevskaya. Each is supposed to continue research and fulfil Russia's commitment to the international programmes in which it participates.

But there could be difficulties in closing the Molodezhnaya base because, under the terms of the Antarctic Treaty, no waste can be left behind. "For this, we need special equipment, containers and many other items that we are unable to buy," says Sergei Khodkin, RHMS deputy head.

Ships must leave Vladivostok no later than October to complete the clean-up before the Antarctic ice becomes too thick. But the cabinet is not scheduled to consider the problem until the first week of September.

Russian ecologists warn that international organizations could employ a private contractor to clean up the Molodezhnaya site, and then send Russia the bill, perhaps with an additional fine. If so, the attempts to save money could end up costing more than keeping the base open.
CarlLevitin 